Contents list avaliable at Directory of Open Access Journals (DOAJ)
Aulad : Journal on Early Childhood
Vol 3 No 2 2020, Pages 69-84
ISSN : 2655-4798 (Printed); 2655-433X (Online)
Journal Homepage: https://aulad.org/index.php/aulad

\title{
Kualifikasi Guru PAUD terhadap Edukasi Spiritualitas Keagamaan Anak Usia Dini
}

\author{
Devi Vionitta Wibowo ${ }^{1}, \mathrm{Na}^{\prime} \mathrm{imah}^{2}$ \\ Pendidikan Islam Anak Usia Dini, Universitas Islam Negeri Sunan Kalijaga Yogyakarta \\ DOI: 10.31004/aulad.v3i2.57
}

Article Info

Kata kunci:

kualifikasiguru

edukasi keagamaan

anak usia dini
Keywords:

teacher qualification

religious education

early childhood

\section{Abstrak}

Penelitian ini bertujuan untuk menjelaskan tentang kualifikasi guru PAUD yang propesional serta implementasinya terhadap edukasi spiritualitas keagamaan bagi anak usia dini. Adanya tulisan ini dapat menambah ilmu pengetahuan tentang teori Abdullah Nashih Ulwan dan Ki Hajar Dewantara dalam konsep pendidikan Islam bagi anak usia dini. Adapun Pendekatan yang digunakan dalam kepenulisan adalah pendekatan kualitatif dengan metode penelitian kepustakaan (studi literatur) melalui analisis teori-teori yang ditentukan. Hasil penelitian menjelaskan bahwa adanya tripusat pendidikan yang terdiri dari keluarga, sekolah dan lingkungan sosial merupakan modal utama dalam penanaman edukasi spiritual keagamaan anak usia dini. TK Al-Furqon Rembang menerapkan edukasi ini melalui program parenting islami, pondok Ramadhan, hafalan Al-Qur'an serta santunan anak yatim, kaum duafa, dan panti jompo. Implementasinya melalui metode pembiasaan dan ceramah. Kualifikasi Guru profesional adalah dengan mempunyai sifat tanggung jawab, berpengetahuan luas, jujur, ikhlas, berprilaku baik, dan menjadikan tauladan bagi anak didiknya.

\begin{abstract}
This research is to explain about professionalis qualification of Early Childhood Education teacher and the implementation of early childhood Islamic education. This research be know about the theories of Abdullah Nashih Ulwan and Ki Hajar Dewantara in the concept of Islamic education for early childhood. This research used qualitative approach to the method of library research (literature study) through the analysis of prescribed theories. The existence of this paper the are educational center consisting of family, school and social environment for Islamic education of early childhood. In The Kindergarten of Al-Furqon Rembang applies Islamic morality education for children with Islamic parenting programs, Ramadhan boarding school, memorizing the Qur'an and donations for orphans, the poor, and nursing homes. Its application through the habituation method and lectures by the professional teachers must be responsibility, knowledgeable, honest, sincere, and good behavior for their students.
\end{abstract}

\footnotetext{
${ }^{1}$ Corresponding author at: Pendidikan Islam Anak Usia Dini, Universitas Islam Negeri Sunan Kalijaga Yogyakarta, Indonesia Email: vionittadevi@gmail.com

${ }^{2}$ Pendidikan Islam Anak Usia Dini, Universitas Islam Negeri Sunan Kalijaga Yogyakarta, Indonesia Email: drnaimah24@gmail.com
} 


\section{PENDAHULUAN}

Pendidikan Islam Anak Usia Dini merupakan pendidikan dasar bagi generasi golden age sebagai pengembangan aspek spiritual, intelektual, psikologi, maupun imajinasi anak melalui berbagai kegiatan yang menyenangkan. Lembaga PAUD tidak dapat maju dan unggul apabila pihak pendidik tidak memiliki kualifikasi terhadap kompetensi profesional dan kepribadian dalam kinerjanya. Adapun tujuan diselenggarakan PAUD adalah untuk menciptakan anak usia dini yang berpengetahuan luas, beramal shaleh, berbudi pekerti yang luhur, berakhlak mulia yang berguna bagi dirinya, agama, bangsa, dan negara (Nata, 2012). Namun ada banyak problematika di zaman sekarang yang semakin memprihatinkan.

Kasus pertama, guru PAUD di Jakarta yang tidak profesional dalam mengasuh dan menjaga anak saat bermain di sekolah. Kasus tersebut menyatakan bahwa anak usia 3 tahun terjatuh dari lantai 2 gedung PAUD, dan mengalami luka di kepala yang cukup serius sehingga dilarikan ke Rumah Sakit terdekat (Trimutia, 2019). Kasus kedua guru PAUD menganiaya anak didiknya yang berumur 3-4 tahun hingga trauma di Samarinda (Rosadi, 2019). Menurut penulis, dari adanya kasus-kasus tersebut dikarenakan kurangnya profesionalitas guru terhadap tanggung jawabnya sebagai pendidik anak usia dini. Guru yang berkualifikasi profesional adalah guru yang memiliki sifat tanggung jawab dalam pendidikan, yaitu mengajar, membimbing, mengasuh, serta dapat menjadi evaluator terhadap capaian perkembangan anak (Novan Ardi Wiyani, 2016). Guru yang profesional juga harus bisa memberikan edukasi spiritualitas kegamaan mengenai pemberian nilai-nilai edukasi agama dan moral kepada anak sejak dini yang penting diapliaksikan dimasa mendatang (Darmadi, 2015).

Adanya edukasi spiritual keagamaan yang diajarkan oleh anak usia dini di lembaga TK merupakan sebuah strategi pendidikan yang baik guna menciptakan pendidikan yang berpegang teguh diatas agama. Adapun tujuan dari adanya penerapan pendidikan Islam pada anak usia dini adalah agar dapat menciptakan anak yang berakhlak mulia yang menjadikan Allah sebagai Tuhan satu satunya di dunia. Selain itu adanya penerapan pendidikan Islam di Lembaga PAUD dapat menumbuhkan ukhwah islamiyah, memperoleh kesejahteraan dalam berinteraksi sosial antar sesama (Inawati, 2017).

Kemampuan profesionalitas berpacu terhadap kepribadian diri seorang guru yang dewasa, bijaksana, bertanggung jawab, berwibawa, penyayang, berakhlak mulia merupakan serangkaian kualifikasi guru ideal yang patut dicontohkan terhadap edukasi spiritual keagamaan Anak Usia Dini (S.Mohammad, 2016). Guna mewujudkan generasi emas yang berbudi luhur dan berakhlak mulia maka, peneliti berencana untuk menganalisis terkait analisis teoritik edukasi spiritualitas keagamaan menurut Abdullah Nashih Ulwan dan Ki Hajar Dewantara dalam mengembangkan kualifikasi profesionalitas guru PAUD yang ideal dalam dunia kependidikan anak usia dini. Harapan dari adanya kepenulisan ini adalah agar mengetahui bagaimana profesionalitas guru terhadap pendidikan Islam bagi anak usia dini. Para guru senantiasa dapat menerapkan model Pendidikan Islam dari Abdullah Nashih Ulwan dan Ki Hajar Dewantara untuk dapat dijadikan landasan dasar kegiatan belajar mengajar. Selain itu dapat dijadikan teladan bagi peserta didik dan masyarakat sekitar yang harus tertanamkan dalam kepribadian guru PAUD.

Untuk bisa menjadi guru yang profesional dan berkepribadian baik, maka tugas guru adalah membenahi diri melalui berbagai kegiatan untuk menambah ilmu pengetahuan, potensi, skill dalam mengajar anak-anak di lembaga PAUD yang disesuaikan dengan impelementasi kurikulum 2013 (Nurmalasari et al., 2013) Guru adalah panutan bersama di sekolah. Guru adalah idola bagi anak-anak. Guru adalah pahlawan tanpa tanda jasa yang mengajar dengan penuh keikhlasan. Maka sudah seharusnya seorang guru menerapkan model-model pendidikan yang cocok dijadikan public figur dan referensi dalam mengajar dan mendidik anak didiknya dengan penuh tanggung jawab dan cinta kasih. Dari latar belakang diatas, maka pokok permasalahan yang akan dikaji adalah 1) bagaimana edukasi spiritualitas keagamaan bagi anak usia dini menurut Abdullah Nashih Ulwan dan Ki Hajar Dewantara, 2) bagaimana Implementasi adanya edukasi keagamaan bagi anak usia dini menurut Abdullah Nashih Ulwan dan Ki Hajar Dewantara, dan 3) bagaimana kualifikasi profesionalitas guru PAUD dalam menerapkan edukasi spiritual keagamaan bagi anak usia dini menurut Abdullah Nashih Ulwan dan Ki Hajar Dewantara.

\section{KAJIAN TEORITIK}

Implikasi dari adanya edukasi spiritualitas keagamaan adalah dengan adanya teori pendidikan dasar Islam yang harus diterapkan. Terdapat dua dasar landasan teoritik terkait teori Pendidikan Islam menurut Abdullah Nashih Ulwan dan teori Pendidikan Islam menurut Ki Hajar Dewantara yang dapat diterapkan oleh guru dalam dunia kependidikan Islam. 


\section{Teori Pendidikan Abdullah Nashih Ulwan}

Syaikh Abdullah Nashih Ulwan adalah pelopor Pendidikan Islam dari Timur Tengah. Beliau dilahirkan di Damaskus, Syiria pada tahun 1928 M. Gelar sarjana dan master beliau peroleh di Universitas Al-Azhar, Kairo. Beliau adalah pengarang sekaligus penulis Kitab Pendidikan Anak Dalam Islam yang berbahasa arab, yaitu Kitab Tarbiyahtul Aulaud Fil Islam (Istiadie \& Subhan, 2016). Abdullah Nashih Ulwan menjelaskan tentang pendidikan Islam bersumber dari Al-Qur'an dan hadis Nabi yang harus diajarkan oleh pendidik dan juga orangtua di rumah, mulai dari jenjang anak-anak hingga dewasa (Arif Rahman Hakim 2012,2). Abdullah Nashih Ulwan adalah seorang pelopor Pendidikan Islam yang menjadi panutan pendidik untuk mendidik anak-anak. karyanya yang terkenal dalam pembahasan pendidikan adalah kitab Tarbiyahtul Aulaud Fil Islam. Kitab tersebut berisikan beberapa petunjuk dalam mendidik serta mengasuh anak-anak secara Islami, yang berpedoman pada Al-Qur'an dan Hadis. Abdullah Nashih Ulwan juga mempunyai pendapat bahwa seorang pendidik hendaknya selalu mencintai anak didiknya dengan penuh cinta kasih seperti anak kandungnya sendiri (Ulwan, 2015).

Abdullah Nashih Ulwan menjelaskan bahwa adanya peranan pendidik dalam mendidik dan mengajarkan suatu pendidikan dimulai sejak anak lahir sampai usia 6 tahun, serta dilanjutkan kembali hingga usia dewasa dengan pemberian pembelajaran yang nyata, motivasi dan pendidikan yang baik bagi mereka. Guru sebagai motivator anak karena gurulah yang memberikan motivasi ke anak didik agar lebih bersemangat dan aktif dalam mengikuti pembelajaran, serta pemberian pujian sebagai apresiasi terhadap keberhasilannya (Ulwan, 2015). Pendidikan Islam yang diajarkan oleh pendidik terdiri dari pendidikan adab yang baik, tanggung jawab, pendidikan yang berlandaskan atas dalil Al-Qur'an dan hadis Nabi, serta mendidik dengan cinta kasih dan sayang. Selain sebagai pendidik dan pengajar, guru juga berperan dalam pembimbing dan pengasuh anak usia dini ketika di sekolah. Ketika anak disekolah guru membimbing terhadap pengetahuannya dan pengalamannya ketika melakukan kegiatan pembelajaran baik di luar kelas maupun di dalam kelas. Abdullah Nashih Ulwan mengajarkan kepada pendidik untuk melatih anak membiasakan diri untuk taat beribadah kepada Allah dan menjauhi larangannya. Pendidik wajib membimbing anak mengenai akidah serta akhlak anak dengan pengenalan terhadap Tuhannya, Nabinya, dan agama serta ibadah-ibadahnya (Agus Wibowo, 2012)

Pendidik juga sebagai pelatih terhadap anak usia dini di sekolah sebagai peningkatan standart tingkat pencapaian pertumbuhan dan perkembangan anak mulai dari latihan keterampilan dalam aspek fisik motorik, bahasa, kognitif, sosial emosional, seni, agama dan moral. Abdullah Nashih Ulwan menyarankan untuk selalu melatih anak tentang kejujuran, menghormati orangtua, tolong menolong, serta melatih cara hidup sehat dengan gemar berolahraga renang, memanah, serta melempar (Ulwan, 2015).

Pendidikan Islam untuk anak-anak tidak luput dari kata bermain. Ketika pendidik bermain dengan anak maka secara tidak sadar pendidik mengajarkan kepada mereka tentang persaudaraan, kasih sayang terhadap teman dan keberanian ketika berada di lingkungan sosial. Abdullah Nashih Ulwan menyarankan bahwa para pendidik hendaknya mengarahkan pada anak didik untuk bermain secara santai, gembira, dapat menyenangkan hati anak dengan berbagai permainan yang edukatif sesuai syariaat Islam (Ulwan, 2015).

Pendidikan juga tidak luput dari evaluasi. Tugas pendidik juga menjadi evaluator bagi anak didiknya. Abdullah Nashih Ulwan mengevaluasi seluruh kegiatan tingkah laku anak dengan menggunakan metode pengawasan agar merasa diperhatikan oleh pendidik. Melalui evaluasi ini guru dapat mengoptimalkan padangan kinerjanya yaitu dengan melihat prilaku anak saat pembelajaran, contohnya mengantuk, tidak fokus, dan merasa bosan saat pembelajarannya (Ulwan, 2015). Evaluasi menjadi sasaran utama dalam menilai setiap pembelajaran dalam pendidikan. Pendidikan Islam tidak luput dari evaluasi karena dengan evaluasi pendidik mampu mengambil infomasi terkait keberhasilan pendidikan yang diterapkan dalam diri anak didik.

\section{Teori Pendidikan Islam Ki Hajar Dewantara}

Ki Hajar Dewantara adalah seorang pelopor Pendidikan ternama di Indonesia. Beliau lahir di kota Yogyakarta pada hari Kamis tanggal 2 Mei 1889. Nama kecil Ki Hajar Dewantara adalah Raden Mas Suwardi Suryaningrat. Ibu beliau adalah seorang permaisuri dari keraton Yogyakarta. Ayahnya bernama Pangeran Suryaningrat seorang putera kerajaan keraton Yogyakarta pada saat itu (Samho \& Yasunari, 2013). Pendidikan menurut Ki Hajar Dewantara ini merupakan pendidikan panutan bagi anak-anak. arti panutan disini adalah segala pembelajaran yang ada dalam nilai-nilai pendidikan yang dapat menumbuhkan dan mengembangkan kompetensi dirinya setinggi-tingginya (Dewantara, 1977). 
Pendidikan yang dicetuskan oleh Ki Hajar Dewantara bernama "Tri Pusat Pendidikan" yaitu gagasan pendidikan yang terbentuk di Indonesia sebagai acuan untuk menumbuhkan sifat tanggung jawab, kasih sayang, budi pekerti, dan ketaatan pada Tuhan yang Maha Esa. Seluruh sifat tersebut harus tertanamkan pada tiga lingkungan dasar, yaitu keluarga, sekolah,dan masyarakat (Utami, 2017). Pendidikan yang dicetukskannya terdiri dari tiga fatwa. Pertama, fatwa tentang pemikiran dan batin manusia. Fatwa ini berpusat pada pemikiran nilai-nilai pendidikan yang ingin menjadikan bangsa Indonesia maju dengan kepribadian yang nyata dan iman yang kuat atas Tuhan yang Maha Esa. Kedua, fatwa tentang pendirian yang tetap dan keberanian yang kuat dalam meluruskan pendidikan di Indonesia. Pendirian dari fatwa ini dapat menjadikan manusia berbudi luhur, berakhlak mulia, menegakkan keadilan serta tawakal. Ketiga, fatwa tentang kesucian dalam berfikir dan kebatinan dalam menegakkan pendidikan. Arti dari fatwa ini adalah berfokus pada religius yang dapat menciptakan perasaan yang tenang, damai dalam hati manusia (Dewantara, 1977).

Adanya semboyan dan metode dalam pendidikan yang dicetuskan oleh Ki Hajar Dewantara menjadi salah satu alternatif pendidikan yang digunakan warga Indonesia dalam menerapkan nilai-nilai pendidikan kepada anak didik. Metode yang cocok untuk pendidikan ini adalah berpacu pada metode penanaman pembiasaan karakter yang harus diterapkan dalam diri manusia. Metode yang digunakan dapat berupa pemberian kasih sayang, cinta damai, tanggung jawab, sopan dalam setiap perilaku, serta baik tutur kata (Dewantara, 1977).

Adapun semboyan pendidikan yang dijadikan landasan dasar pembelajaran yang dilakukan pendidik adalah semboyan khas Ki Hajar Dewantara yang berbunyi "Ing Ngarso Sung Tulodo, Ing Madya Mangun Karsa, Tut Wuri Handayani" yang artinya didepan memberi tauladan, di tengah memberi bimbingan, di belakang memberi dorongan. Makna dari arti kalimat tersebut adalah disamping menjadi tauladan atau panutan yang baik, di tengah memberikan semangat juang dan selalu memberikan dorongan moral, sehingga seseorang dapat merasakan persahabatan dalam meraih pendidikan sehingga kedepannya dapat menjadikannya manusia yang baik dimata masyarakat kelak (Syaikhudin, 2012).

Menurut Ki Hajar Dewantara, sebuah pendidikan tidak akan maju jikalah tidak ada lingkungan yang mendukung sebagai subyek pendidikan bagi tumbuh kembang anak. Adanya tri pusat pendidikan yang menjadi modal dasar pendidikan yang berfilosofi. Tri pusat pendidikan tersebut terdiri dari lingkungan keluarga, sekolah, dan masyarakat. dalam lingkungan keluarga, pendidikan berperan aktif dalam memberikan pengalaman pertama pada masa kanak-kanak, memberikan motivasi dan dorongan atas terjaminnya emosional anak, memberikan arahan dan bimbingan atas tumbuhnya moralitas anak, memberikan berbagai macam pendidikan sosial kepada anak, serta menumbuhkan dari dalam diri anak tentang dasar-dasar pendidikan spiritualitas keagamaan pada anak sejak dini (Ki Suratman, 1987).

Jika lingkungan sekolah, Ki Hajar Dewantara menerapkan pendidikan sebagai pelengkap dari pendidikan yang ada di lingkungan keluarga. Sudah sepatutnya tidak semua tugas orangtua di rumah dapat dilaksanakan oleh pendidik di sekolah. Guru sebagai pelengkap sekaligus penambah pendidikan baik formal maupun informal kepada anak-anak. Fungsi sekolah menurut Ki Hajar Dewantara adalah sekolah membantu perlengkapan pendidikan yang tidak dilakukan di lingkungan keluarga sehingga dapat didapat di lingkungan sekolah, sekolah sebagai acuan dasar untuk mendapatkan ilmu pengetahuan yang nantinya akan ada manfaatnya di masa mendatang ketika terjun bersama masyarakat sekitar sekolah juga menerapkan, mengajarkan, dan melatih pembelajaran yang penting didapat oleh anak, yaitu membaca, menulis, berhitung, menggambar, serta berbagai ilmu pengetahuan yang dapat menambahkan potensi keilmuan anak didik (Nugroho, 2018).

Sekolah juga berperan aktif dalam penanaman akhlak mulia, pemberian pendidikan spiritual keagamaan, penerapan estetika kehidupan, serta pengembangan ide dan imajinasi anak. sekolah juga tempat untuk memperoleh suatu informasi mengenai budaya nenek moyang yang harus dilestarikan sebagaimana mestinya (Juhji, 2016).

Jika lingkungan masyarakat, menurut Ki Hajar Dewantara dapat menerapkan pendidikan sebagai kesadaran sosial, interaksi-interaksi dari sebuah percakapan pada ognanisasi muda. Hubungan pendidikan dengan masyarakat adalah dapat menjalin ukhwah islamiyah persatuan dan kesatuan bangsa. Selain itu masyarakat juga berperan aktif dalam penyediaan sumber belajar bagi anak didik. Media masa seperti televisi, internet, iklan, poster salah satu unsur utama dari pendidikan Islam yang dikeluarkan dalam mensukseskan pembelajaran anak (Nurhayati, 2013). 


\section{METODE PENELITIAN}

Jenis penelitian ini adalah penelitian kepustakaan (library research) artinya sebuah studi dengan mengkaji teori dari buku-buku, naskah-naskah, majalah-majalah yang bersumber dari khazanah kepustakaan yang relevan dengan tema yang diangkat dalam penelitian. Penelitian ini menggunakan pendekatan kualitatif deskriptif. Pendekatan kualitatif lebih berpusat pada teori berdasarkan konsep yang akan dibahas (Sugiyono, 2015). Penelitian dilakukan berdasarkan ilmu pengetahuan yang empiris guna mendapatkan hasil analisis teoritik yang empiris pula. Penelitian studi pustaka menganalisis teori-teori yang yang bersumber dari data primer dan data sekunder. Pertama, data primer yang digunakan dalam penelitian ini mencangkup analisis edukasi spiritualitas keagamaan anak usia dini melalui teori Pendidikan Islam menurut Abdullah Nashih Ulwan dan Ki Hajar Dewantara. Teori diambil dari buku-buku, ataupun artikel yang ada kaitannya dengan materi, kemudian dianalisis. Buku yang dapat dijadikan rujukan adalah Kitab Tarbiyatul Aulad Fil Islam sebagai buku penunjang Pendidikan Islam karangan Abdullah Nashih Ulwan dan buku-buku karangan Ki Hajar Dewantara yang menjelaskan tentang Pendidikan dan Taman Siswa.

Kedua, data sekunder yaitu membahas tentang pokok permasalahan yang terkait pada penelitian, yaitu analisis edukasi spiritualitas keagamaan anak usia uini terhadap kualifikasi profesionalitas guru PAUD. Analisis teori ini dilakukan secara deskriptif berdasarkan hasil pengamatan yang telah ditemukan dalam buku, dokumen, artikel, maupun penelitian terdahulu. Penelitian ini juga menggunakan teknik analisis data wawancara untuk mendapatkan dokumentasi atau data terkait implentasi edukasi spiritualitas keagamaan anak usia dini. Adapun tempat yang dituju adalah TK/RA Al-Furqon, yaitu lembaga Pendidikan Islam maju di Rembang, Jawa Tengah. Setelah data terkumpul, penulis menganalis teori-teori tersebut dengan menambahkan informasi lanjut yang berlandaskan atas penelitian terdahulu yang relevan dengan materi yang dianalisis. Penelitian terdahulu dijadikan sumber data-data kemudian dianalisis berdasarkan kebutuhan peneliti dalam menjawab rumusan masalah yang dibuat. Selain itu penulis juga menggunakan gagasan serta ide-ide kreativ sendiri agar dapat menyempurnakan artikel ini. adapun alur penelitian sebagai berikut;

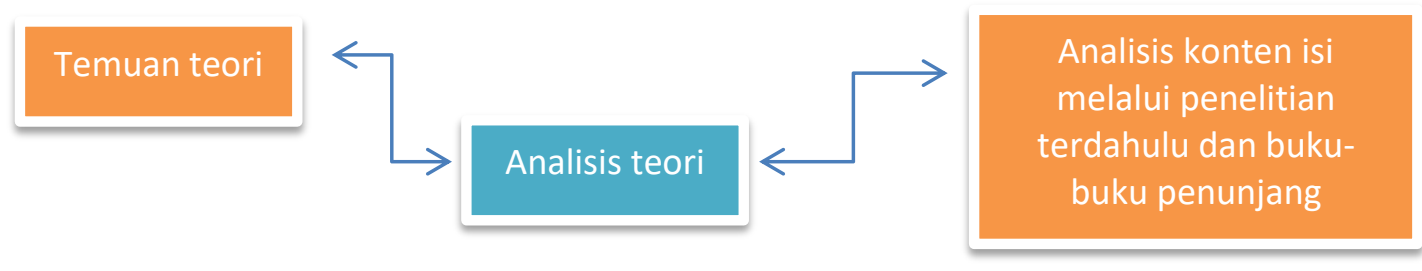

Gambar 1 Alur Penelitian Pustaka Teoritik

\section{HASIL DAN PEMBAHASAN}

Analisis Edukasi Spiritualitas Keagamaan menurut Abdullah Nashih Ulwan terhadap Pendidikan Anak Usia Dini

Menurut teori pendidikan Abdullah Nashih Ulwan, ada beberapa prosedur pendidikan yang dapat diajarkan kepada anak usia dini yang dapat menjadi landasan dasar pendidik dalam menerapkan tugas dan peranannya di Sekolah. Pendidik pada dasarnya adalah sebagai pahlawan tanpa tanda jasa yang ikhlas mengabdi kepada masyarakat dengan berbagi ilmu pengetahuan kepada anak-anak. Melalui pendidikan, anak usia dini dapat tumbuh dan berkembang sebagaimana mestinya. Pada dasarnya pendidikan anak usia dini dilakukan guna memenuhi kebutuhan anak dalam segi pertumbuhan dan perkembangannya untuk tumbuh dan berkembang dengan baik agar dapat menunjang ke jenjang sekolah selanjutnya. Pendidikan anak usia dini dilakukan dari usia 06 tahun yang dapat diterapkan di lembaga formal ataupun informal misalnya RA/BA/KB/TK dan sederajatnya (Ariyanti, 2016).

Pendidikan Islam yang diajarkan oleh Abdullah Nashih Ulwan tidak luput dari sebuah dalil Al-Qur'an dan hadis Nabi. Menurut penelitian yang dilakukan Harpansyah dalam skripsinya yang berjudul "Pendidikan Anak dalam Perspektif Abdullah Nashih Ulwan ( Telaah Atas Kitab Tarbiyatul Aulad Fil Islam)" menyatakan bahwa pendidikan anak dalam perspektif Abdullah Nashih Ulwan dalam kitab Tarbiyatul Aulad Fil Islam ada beberapa isi mengenai pendidikan anak diantaranya adalah tanggung jawab orangtua atau pendidik terhadap pendidikan anak dari aspek agama dan moral, fisik, inteletual, hingga pendidikan seks untuk anak. Dalam kitab ini juga terdapat metode penanamannya, diantaranya adalah metode nasehat, pembiasaan, prestasi (Harpansyah, 2017). Penelitian 
jurnal juga menyatakan bahwa ruang lingkup edukasi spiritualitas agama anak usia dini menurut Abdullah Nashih Ulwan adalah pendidikan keimanan terhadap Allah agar selalu cinta terhadap Allah, Malaikat, dan Nabi, menjauhi larangan-larangan agama, dan mempercayai agama Islam sebagai agamanya (Khairil Mustofa, 2014). Selain itu adanya Edukasi moralitas spiritual keagamaan yang diterapkan oleh Abdullah Nashih Ulwan dengan beberapa prilaku akhlak baik, yaitu berbakti kepada orangtua, bersikap sopan santun dan ramah juga harus diterapkan kepada anak usia dini (Yusuf, 2017).

Menurut penulis dari penelitian-penelitian diatas, dapat dianalisis bahwa pendidik berperan aktif dalam mendidik dan mengajarkan edukasi spiritual keagamaan yang terdiri dari pengajaran agama dan moral yang baik yang dimulai sejak dini. Pendapat ini tertera dalam kebijakan UUD No. 20 Tahun 2003 pasal 28 Ayat 1 tentang Sistem Pendidikan Nasional yang menyatakan bahwa diwajibkan untuk melakukan pendidikan yang dilakukan sejak mereka usia 0-6 tahun (Suyadi, 2011). Implementasinya yaitu melalui proses yang melibatkan kognitif, emosi, dan fisik yang dapat diciptakan melalui prilaku kejujuran, sopan santun yang diterapkan oleh pendidik dengan metode keteladanan yang baik (Ananda, 2017). Benar adanya bahwa Abdullah Nashih Ulwan berpendapat edukasi Islami berlandaskan atas dasar akhlak yang baik, mencintai Allah dan Nabi, dan gemar menerapkan isi kandungan Al-Qur'an. Paparan di atas dikuatkan oleh sebuah sabda Nabi saw (Ulwan, 2015).

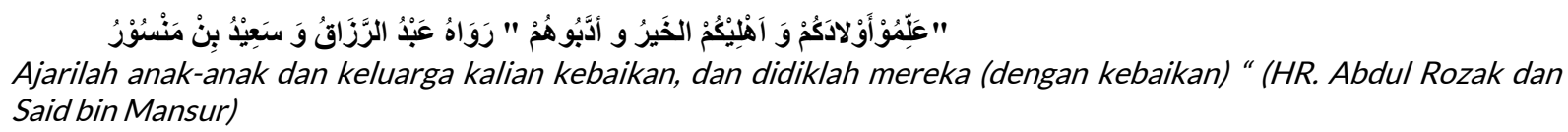

Pendidikan yang diterapkan oleh Abdullah Nashih Ulwan berpacu pada tugas pendidik dalam mengajar, mendidik, mengasuh, melatih, dan menilai pembelajaran dalam pendidikan. Abdullah Nashih Ulwan mengajarkan kepada anak-anak dengan kasih sayang sebagai modal dasar mendidik dan mengajarkan tentang adab yang baik, mencintai Allah, Nabi, orangtua, serta mempererat tali silaturahmi antar sesama (Wiyani, 2017). Pendidikan bagi Abdullah Nashih Ulwan menerapkan agar pendidik membimbing dan melatih kemampuan potensi perkembangan anak. pendidik membimbing mereka dengan mengarahkan kebaikan dengan pemberian tauladan kepada anakanak. kegiatan membimbing ini dilakukan guru ketika sedang melakukan kegiatan belajar mengajar di kelas maupun di luar kelas. Setelah dibimbing, pendidik melakukan kegiatan pelatihan berupa memberikan berbagai kegiatan edukatif yang bermanfaat untuk anak. Abdullah Nashih Ulwan menerapkan pelatihan hidup sehat sebagai pelatihan yang menyenangkan dengan kegiatan permaianan memanah, berenang, dan melempar. Selain itu pendidik melatih mereka untuk selalu berbuat baik antar sesama, berkata jujur saat berbicara, serta menghormati orang yang lebih tua di sekolah (Daud, 2019).

Betapa pentingnya ulasan Abdullah Nashih Ulwan tentang pentingnya edukasi Islami bagi anak usia dini. pendapat ini tertera dalam kitab Tarbiyatul Aulad Fil Islam yaitu;

"Dari Kitab ini, dapat menyelesaikan permasalahan anak-anak dari mereka lahir sampai mereka berusia dewasa, dan menikah. Kitab ini juga menyelesaikan segala permasalahan tentang keimanan, psikologi (kepribadian), sosial dan moral anak. Kitab ini disesuaikan dengan Al-Quran dan hadist dan sebagian pendapat para ulama sholeh terdahulu. Maka dari itu, sesungguhnya kitab ini telah diterbitkan khusus untuk mengetahui isi kitab dan dasar pendidikan"(Ulwan, 2015).

Selanjutnya adanya saran-saran pendidikan yang dikatakan oleh Abdullah Nashih Ulwan yaitu untuk merangsang dan menstimulasi pendidikan Islam untuk anak usia dini. Maka disini tugas seorang pendidik ataupun orang tua adalah mendidik dengan cinta kasih berpegang teguh pada Al-Qur'an dan Hadis Nabi. Berikut ulasan Abdullah Nashih Ulwan mengenai hal tersebut

"Beliau (Syaikh Wahabi Sulaiman Al-Gawajji Al-Albani) memandang mengenai saran-saran pendidikan dari Syaikh Abdullah Nashih Ulwan adalah sebagai berikut (Ulwan, 2015) : a) merangsang anak untuk mendapatkan mata pencaharian yang mulia dengan tetap memerhatikan kesiapan fitrah anak, b) memberikan ruang bagi anak untuk bermain dan beristirahat (mewujudkan hubungan antara rumah, masjid dan sekolah), 3) menguatkan hubungan antara pendidik dengan anak, 4) menerapkan metode pendidikan setiap saat, 5) menyediakan saranasarana yang bisa menambah wawasan bagi anak, 6) merangsangnya untuk selalu gemar aktifitas penelaahnya, dan 6) memberikan rasa tanggung jawab kepada Islam pada dirianak. 
Pendidikan anak usia dini, tidak luput dari sebuah permainan yang edukatif untuk diterapkan di sekolah. Bermain merupakan proses anak dalam belajar. Pendidik berperan langsung dalam bermain dan mempraktekkan kepada anak dengan berbagai alat permainan edukatif yang menyenangkan dan menarik bagi anak. Anak usia dini harus diarahkan ketika bermain. Sudah menjadi kewajiban seorang pendidik untuk mengarahkan permainan anak dengan bermain dengan penuh kasih sayang antar sesama. Diharapkan seorang pendidik membimbing anak saat bermain. Penelitian menyatakan bahwa bermain juga dapat mengembangkan psikologis anak, maka tugas pendidik baik orangtua ataupun guru adalah sebagai pembimbing dan wajib menyisipkan unsur edukasi kepada anak, serta selalu memberikan penilaian terhadap psikologi perkembangan anak dari kegiatan bermain (Rohmah, 2016).

Setelah kegiatan pembelajaran berlangsung dengan baik, maka alur pendidikan selanjutnya adalah mengevaluasi dengan menilai berbagai kegiatan yang diajarkan oleh pendidik. Evaluasi pembelajaran sangat diperlukan untuk mengambil informasi terkait keberhasilan pendidikan yang diterapkan oleh anak-anak (Saripudin \& Faujiah, 2018). Pendidik harus mempunyai talenta dan kemampuan untuk menilai kegiatan perkembangan anak dengan menggunakan instrumen penilaian yang diterapkan sesuai dengan jenis kegiatan yang dilakukan. Melalui evaluasi ini guru dapat mengoptimalkan padangan kinerjanya yaitu dengan melihat prilaku anak saat pembelajaran, contohnya mengantuk, tidak fokus, dan merasa bosan (Carol S Lidz, 2002). Adanya kegiatan evaluasi ini dapat menjadi tombakan bagi para pendidik agar dapat memahami hasil asesmen yang dilakukan di PAUD, kemudian agar dapat mengetahui efektivitas metode, media, dan sumber pembelajaran yang digunakan di PAUD.

Dari data-data diatas, maka dapat disimpulkan bahwa adanya pendidikan Islam yang dapat diterapkan oleh anak usia dini dalam kitab Tarbiyatul Aulad Fil Islam dengan berpacu pada hal-hal berikut;

Tabel 1 Analisis Edukasi Spiritual Keagamaan Abdullah Nashih Ulwan Terhadap Anak usia dini

\begin{tabular}{|c|c|}
\hline Tanggung jawab pendidik & Strategi pembelajaran \\
\hline Pendidikan keimanan & $\begin{array}{l}\text { Pengajaran, pendidikan, evaluasi tentang pembelajaran IMTAQ (Keimanan dan } \\
\text { Ketaqtawaan, membaca dan mentadabur Al-Qur'an, mencintai Allah dan } \\
\text { NabiNya, memperkenakan dan melakukan Ibadah }\end{array}$ \\
\hline Kepribadian & $\begin{array}{l}\text { Berkata jujur, berbakti kepada orangtua, membiasakan berprilaku sopan santun } \\
\text { terhadap orang yang lebih tua. }\end{array}$ \\
\hline Sosial dan moral anak & $\begin{array}{l}\text { Bersilaturahmi terhadap anak yatim dan anak jalanan, berakhlakul karimah } \\
\text { dengan teman dan guru di kelas, mengajarkan kasih sayang terhadap sesama. }\end{array}$ \\
\hline
\end{tabular}

\section{Analisis Edukasi Spiritualitas Keagamaan dalam Teori Pendidikan Ki Hajar Dewantara bagi Anak Usia Dini}

Menurut teori pendidikan Ki Hajar Dewantara pendidikan diibaratkan sesuatu yang harus dilakukan dan dikerjakan oleh putra-putri anak bangsa untuk mendapatkan pendidikan yang relevan sebagai modal masa depan bangsa. Pendidikan Islam yang diterapkan oleh Ki Hajar Dewantara bersumber pada keadaan batiniah dan lahiriyah. Pendidik mengaplikasikan pendidikan ini berdasarkan kenyakinan terhadap pendidikan spiritual keagamaan yang diajarkan dan dibiasakan oleh anak didik.maka dari itu pendidik terutama guru harus menjadi contoh tauladan yang baik bagi anak didiknya (Aziz, 2017). Pendidikan yang diterapkan oleh Ki Hajar Dewantara berpusat pada tri pusat pendidikan, yaitu keluarga, sekolah, dan masyarakat. Ini adalah momentum utama dalam mendidik dan membimbing anak didik. Anak usia dini sangat membutuhkan pendidikan di lingkungan keluarga, sekolah, dan masyarakat. Anak-anak dididik spiritual keagamaannya pertama kali di lingkungan keluarga. Kemudian sebagai pelengkap, pendidik mengajarkan dan membiasakan pendidkan spiritual keagamaan di lingkungan sekolah. Kemudian masyarakat berperan aktif dalam penyediaan fasilitator sebagai pendukung (Ikhwan, subandi, 2018).

Pendidikan Islam yang diterapkan oleh Ki Hajar Dewantara pada dasarnya perlu untuk diaplikasikan terhadap anak diusianya yang masih dini. Anak usia dini membutuhkan banyak bimbingan, stimulus terhadap perkembangan dan pertumbuhannya. Anak usia dini membutuhkan pengasuhan yang berkesinambungan sebagai stimulus mereka menuju perkembangan dan pertumbuhan yang pesat. Pendidikan Ki Hajar Dewantara ini adalah modal utama dalam mencetuskan potensi-potensi yang tinggi atas minat dan bakat kepada anak didik terutama anak usia dini. Anak usia dini berpotensi untuk tumbuh dan berkembang dengan adanya pendidikan dengan rasa kasih sayang, tanggung jawab, dan adil. Maka dari itulah para penelitian menerapkan bahwa sistem edukasi spiritual agama anak usia dini ada pada tripusat pendidikan, budi pekerti dengan implementasi sistem belajar 
sambil bermain agar anak nyaman saat belajar (Rohmatun Nurul Hidayah, 2015). Disini peran pendidik adalah sebagai pendidik, pengajar, pembimbing sekaligus publick figur atau tauladan yang baik bagi anak usia dini.

Maka tidak dipungkiri, jikalah seorang pendidik di Sekolah sebagai artis sekaligus ibu bagi anak usia dini. Semua perkataan dan perbuatan pendidik direkam dan diikuti sebagai penambahan ilmu pengetahuan. Adanya tiga ruang lingkup pendidikan yang dicetuskan oleh Ki Hajar Dewantara meliputi keluarga, sekolah, dan masyarakat. Keluarga mempunyai peranan penting dalam pertumbuhan dan perkembangan anak usia dini. Keluarga merupakan madrasahtul ula atau sekolah pertama bagi anak usia dini. Dalam lingkungan keluarga, anak-anak belajar akan kebiasan-kebiasan baik dan kosa kata ibu sebagai bahasa pemula. Penerapan pendidikan di lingkungan keluarga dapat menjadikan acuan utama untuk menumbuhkan pribadi yang unggul dalam diri anak usia dini. Anak dididik dan diarahkan serta dibiasakan untuk selalu mencintai Allah, mengamalkan ibadah-ibadah wajib sebagai tanda ketekunan terhadap Tuhannya. Anak dididik agar mengormati orangtua, kejujuran, dan kasih sayang (Fajarini, 2014).

Ketika pendidikan diarahkan pada sekolah, maka yang berhak untuk bertanggung jawab atas semua ini adalah semua stakeheldor sekolah, baik kepala sekolah maupun pendidik guru yang berperan dalam mensukseskan pendidikan yang ada di sekolah. Model pendidikan Ki Hajar Dewantara tidak luput dari penerapan pengajaran dan pendidikan yang dilahirkan atas dasar batiniah lahiriah dalam menumbuhkan potensi-potensi dari minat bakat anak didik. Sistem pendidikan yang sesungguhnya ada pada kegiatan mengasuh, membimbing, mengajar, mendidik, dan melatih anak didik dalam proses pembelajarannya. Sifat umum yang diterapkan dalam pendidikan sekolah menurut Ki Hajar Dewantara ini ada pada penumbuhan karakter dalam kebiasaan-kebiasaan kesehariannya. Tugas utama guru PAUD adalah menyenangkan hati anak didik ketika di sekolah dengan cara membebaskan mereka untuk bereksplorasi, bereksperimen, bermain serta berimajinasi saat kegiatan pembelajaran (Pradipto, 2007). Maka peneliti berpendapat bahwa sistem among edukasi spiritual agama terhadap anak usia dini ada pada suri tauladan orangtua maupun guru dalam mengimplementasikan edukasi agama dan moral yang bersumber pada tripusat pendidikan Ki Hajar Dewantara.

Selain itu sebuah penelitian menyatakan bahwa pendidikan yang diterapkan adalah ada pada lingkungan masyarakat. Lingkungan masyarkat berguna sekali bagi pengembangan budaya bangsa. Selain budaya, pendidikan lingkungan masyarakat berperan aktif dalam penyediaan fasilitator guna terciptanya pendidikan yang maju. Disini peranan kepala sekolah bahkan guru ada pada sistem ini. penyedian fasilitas bahkan peningkatan prestasi belajar ada pada hal ini (Karoso \& Trihantoyo, 2017). Menurut peneliti beberapa pelatihan, seminar, aplikasi bimbel online menjadi salah satu bukti nyata bahwa pendidikan di ranah lingkungan masyarakat berjalan sangat pesat. Masyarakat ini meliputi pemerintah, warga desa yang turut berpartisipasi dalam mensukseskan pendidikan Indonesia. Anak usia dini dapat diajarkan tentang pengenalan kebudayaan dalam konsep pendidikan. Untuk mengenalkan kebudayaan di lingkungan sekitar, maka Anak usia dini dapat diajak di tempat musium kerajinan tangan, batik, pagelaran seni, pengenalan kebudayaan tari, bahasa, dan makanan antar daerah. Kegiatan ini merupakan sebuah pendidikan bagi anak usia dini, agar mereka mengetahui betapa besarnya budaya masyarakat yang dijadikan pendidikan selain di sekolah, maupun di keluarga. Berikut analisis pendidikan Ki Hajar Dewantara dilihat dari tiga pusat pendidikan untuk anak usia dini.

Tabel 2 Analisis Tri Pusat Pendidikan Ki Hajar Dewantara untuk Anak Usia Dini

\begin{tabular}{|c|c|c|c|}
\hline $\begin{array}{c}\text { Tri pusat } \\
\text { Pendidikan }\end{array}$ & Kegiatan & Metode & Stakeholder \\
\hline Keluarga & $\begin{array}{l}\text { Menghormati orangtua, membaca, } \\
\text { menulis, bercerita, beribadah } \\
\text { kepada Allah, menerapkan adab } \\
\text { yang baik }\end{array}$ & $\begin{array}{l}\text { Pembiasaan } \\
\text { Pengawasan, } \\
\text { Pelatihan, }\end{array}$ & $\begin{array}{l}\text { Orangtua, ayah ibu, kakak, } \\
\text { paman, bibi. }\end{array}$ \\
\hline Sekolah & $\begin{array}{l}\text { Kreativitas, eksperimen, bercerita, } \\
\text { membaca, menulis, berhitung, } \\
\text { pembiasaan adab yang baik, } \\
\text { bermain }\end{array}$ & $\begin{array}{l}\text { Pembiasaan, pengawasan, } \\
\text { pelatihan, } \\
\text { pembimbingan,pengajaran, } \\
\text { pengasuhan }\end{array}$ & $\begin{array}{l}\text { Kepala sekolah, guru, komite } \\
\text { sekolah, tenaga kependidikan }\end{array}$ \\
\hline $\begin{array}{l}\text { Lingkungan } \\
\text { sosial }\end{array}$ & $\begin{array}{l}\text { Pelatihan mendongeng seminar } \\
\text { parenting, kursus online, } \\
\text { perlombaan kreativitas, penyediaan } \\
\text { informasi seputar pendidikan anak }\end{array}$ & $\begin{array}{l}\text { Pelatihan, } \\
\text { eksplorasi, } \\
\text { pengajaran }\end{array}$ & $\begin{array}{lr}\text { Pemerintah, } & \text { masyarakat, } \\
\text { kementrian } & \text { Pendidikan dan } \\
\text { Kebudayaan, } & \text { Kementrian } \\
\text { Perlindungan anak } & \\
\end{array}$ \\
\hline
\end{tabular}


Sebuah penelitian mengungkapkan bahwa tri pusat pendidikan yang diajarkan oleh Ki Hajar Dewantara merupakan sistem among pendidikan, yaitu sistem among yang mengajarkan keluarga, sekolah, lingkungan sebagai bagian dari pendidikan. Sistem among ini bagian dari edukasi spiritual keagamaan yang memiliki fungsi untuk mendekatkan anak didik pada sebuah kepercayaan Ketuhanan Yang Maha Esa, serta berbudi luhur dan baik (Susilo, 2018). Menurut teori Lickona tri pusat pendidikan yang diajarkan oleh Ki Hajar Dewantara merupakan sebuah edukasi spiritual keagamaan guna meningkatkan keagamaan serta karakter bagi anak usia dini. Sistem among tersebut dikerjakan dengan sebuah pembiasaan yang menyertakan metode asih asah dan asuh terhadap anak usia dini (Sudaryanti, 2017). Menurut penulis dari penelitian tersebut adalah merupakan salah satu asas menuju kesuksesan dalam penanaman edukasi spiritual kegamaan dalam teori pendidikan Islam menurut Ki Hajar Dewantara yang terdiri dari sistem among tri Pusat Pendidikan, yaitu Sekolah, Rumah, dan lingkungan sosial yang berkarakter.

\title{
Implementasi Pendidikan Islam Anak Usia Dini berdasarkan teori Abdullah Nashih Ulwan dan Ki Hajar Dewantara di TK/RA AlFurqon Rembang
}

Telah kita ketahui bahwa model pendidikan Islam yang diajarkan oleh Abdullah Nashih Ulwan dan Ki Hajar Dewantara terhadap anak usia dini, tidak lepas dari tiga ruang lingkup tempat pendidikan. Tiga tempat pendidikan tersebut adalah keluarga, sekolah, dan lingkungan. Abdullah Nashih Ulwan berpendapat bahwa

"Dan apabila diberikannya sebuah kesadaran pendidikan yang yang diberikan pada lingkungan keluarga ( rumah ), dan campuran sosial yang bagus, dan pada lingkungan pembelajaran yang efesien, maka tidak diragunakan lagi, bahwa anak tersebut mempunyai keimanan yang kuat, memiliki akhlak yang mulia, dan pendidikan yang baik." (Ulwan, 2015)

Dan pendapat Ki Hajar Dewantara tentang tripusat pendidikan yang menjelaskan bahwa pendidikan yang diajarkan bersumber dari tiga trupusat, yaitu pendidikan di keluarga, sekolah, dan lingkungan masyarakat yang mengajarkan akan berbagai budaya bangsa. Berikut pemaparan datanya;

\begin{abstract}
"Pendidikan tidak akan maju jikalah tidak ada lingkungan yang mendukung sebagai subyek pendidikan bagi tumbuh kembang anak. Adanya tri pusat pendidikan yang menjadi modal dasar pendidikan yang berfilosofi. Tri pusat pendidikan tersebut terdiri dari lingkungan keluarga, sekolah, dan masyarakat. Lingkungan keluarga berperan aktif dalam memberikan pengalaman pertama pada masa kanak-kanak, memberikan motivasi dan dorongan atas terjaminnya emosional anak, memberikan arahan dan bimbingan atas tumbuhnya moralitas anak, memberikan berbagai macam pendidikan sosial kepada anak,yang bersumber terhadap budaya bangsa" (Ki Suratman, 1987).
\end{abstract}

TK/RA Al-Furqon merupakan suatu Lembaga Pendidikan Islam bertaraf qur'ani. Sekolah ini merupakan sekolah favorit Islami di kota Rembang, Jawa Tengah. Sekolah ini dinamakan LPI Al-Furqon. Hal tersebut dikarenakan lembaga ini merupakan salah satu bagian yang di kelola oleh yayasan Pondok Pesantren Al-Furqon milik Dr H Arif Budiman MP.d. Beliau adalah anak dari ketua yayasan Pondok Pesantren Al-Fuqon, Kasingan kabupaten Rembang, Jawa Tengah. Lembaga Pendidikan Islam ini berada di Desa Kasingan tepatnya jalan. Pesantren No.2 Kelurahan Sukoharjo Kabupaten Rembang. Kepala sekolah TK/RA Al-Furqon, Bapak Dididk Purwanto, S.Pd menyatakan bahwa visi misi, dan tujuan Al-Furqon sebagaimana dalam tabel berikut.

Tabel 3 visi, misi dan tujuan TK/RA Al-Furqon

\begin{tabular}{lll}
\hline Visi & Membentuk insan muttaqin dan qurani \\
\hline Misi & 1. & Beriman dan dan taat mengamalkan ajaran al-quran \\
& 2. & Membaca, menghafal, mengamalkan al-quran dalam kehidupan sehari-hari. \\
& 3. & Berakhlak mulia, hidup unggul, tertib, mandiri dan kreatif. \\
& 4. & Berwawasan pengetahuan untuk kesejahteraan sosial. \\
& 5. & Membudayakan anak didik untuk berprilaku islami dalam kehidupan sehari-hari. \\
\hline Tujuan & 1. & Ikut serta dalam pembangunan bangsa Indonesia dengan memajukan Pendidikan Nasional. \\
& 2. & Mencetak insan bertaqwa, berakhlak mulia, berpengetahuan luas, memiliki kemampuan teknologi \\
& 3. & Ian peduli pada lingkungan. \\
& & pengembangan pendidikan. \\
\hline
\end{tabular}


Pengajaran pendidikan di TK/RA Al-Furqon ini memiliki pengajaran dan pembelajaran pendidikan Islam yang berteorikan Abdullah Nashih Ulwan dan Ki Hajar Dewantara. TK/RA ini mengajarkan pendidikan Islam berupa keimanan, akhlak, dan sosial yang dirangcang dalam tiga lingkup lingkungan pendidikan, yaitu berasaskan keluarga, sekolah, dan masyarakat. Program pembelajaran yang melingkupi hal tesebut adalah program parenting islami, pondok Ramadhan, hafalan surat-surat pendek yang dijadikan program unggulan, pengadaan edukasi lapangan berupa santunan anak yatim, kaum duafa, dan panti jompo untuk dijadikan pembelajaran sosial simpati dan empati yang termasuk dalam pendidikan akhlakul karimah. Pendidikan Islam yang diterapkan di TK/AI-Furqon menggunakan metode pembiasaan, pelatihan, dan ceramah. Metode pembiasaan adalah metode yang dilakukan dengan cara berulang-ulang (Majid, 2013). Pendidikan Islam dapat diterapkan melalui metode pembiasaan yang dapat dilakukan untuk membiasakan anak usia dini agar dapat berfikir, bersikap, dan bertindak sesuai dengan tuntunan ajaran Islam (Zainal aqib, 2013).

Implementasi ini juga sudah diterapkan pada penelitian tesis oleh Nining Umi Salmah, tahun 2018 dalam penelitiannya yang berjudul komunikasi guru dan orangtua dalam penanaman nilai-nilai keagamaan di TK ABA Sidomulyo II Bantul. Hasil penelitian menyatakan bahwa pendidikan Islam yang diterapkan oleh anak usia dini tidak luput pada tiga sumber pendidikan, yaitu keluarga, selalu berkomunikasi dengan surat kabar, telepon, group whatsaap, dan rapat rutinan. Penanaman Pendidikan Islam di Sekolah, sama dengan penanaman pendidikan Islam yang diterapkan di ranah keluarga, yaitu pendidikan Akidah, akhlak, dan sosial. metode yang digunakan yaitu bercerita, pembiasaan, keteladanan yang dilakukan guru dan orangtua serta masyarakat sekitar.

\section{Kualifikasi Profesional Guru terhadap Edukasi Spiritual Keagamaan Anak Usia Dini}

Guru dapat diibaratkan sebagai titik terpenting dalam pendidikan. Seorang guru mempunyai tugas yang terpenting dalam menciptakan anak-anak yang unggul dan intelek. Tugas utama guru PAUD adalah menyenangkan hati anak didik ketika di sekolah dengan cara membebaskan mereka untuk bereksplorasi, bereksperimen, bermain serta berimajinasi saat kegiatan pembelajaran (Pradipto, 2007). Pendapat tersebut sangatlah benar, dikarenakan guru merupakan salah satu orang yang terpenting dalam memberikan pendidikan di Sekolah. Semboyan Ki Hajar Dewantara telah menyebutkan bahwa kata guru berasal dari sekolah, dan masyarakat. lingkungan keluarga, pendidikan Islam diterapkan dan dibiasakan, serta diajarkan oleh orangtua. Orangtua mempunyai peranan penting dalam penanaman pendidikan Islam anak, seperti pendidikan akidah, akhlak, dan sosial. Pendidikan akidah yaitu anak diajarkan mengenal Allah, Nabi, sholat, puasa, membaca Al-Qur'an. Pendidikan akhlak diajarkan prilaku baik, pembiasaan kejujuran, berbakti kepada orangtua. Pendidikan sosial yaitu pembiasan dan latihan berbuat baik dan saling menyapa tetangga. Guru dan orangtua

bahasa jawa, yaitu "digugu lan ditiru" yang artinya guru itu adalah seorang public figuryang memberikan suri tauladan yang baik yang dapat dijadikan contoh kepada anak didiknya.

Selain itu, adanya filsafat moral utilitarisme menjadi penelitian yang mendukung mengenai kualifikasi guru yang profesional menurut Ki Hajar Dewantara. Hasil penelitian menyatakan bahwa etika guru yang berkualifikasi terletak pada prilakunya yang dapat dijadikan contoh sistem among pada anak didiknya, kemudian guru harus berpegang teguh pada agama Ketuhanan yaitu memiliki keimanan, berjiwa wibawa dan tanggung jawab, serta kasih sayang saat mendidik dan mengajar mengajar (Ibrahim \& Hendriani, 2017). Menurut penulis, guru adalah salah satu profesi yang memiliki jasa yang sangat besar dalam mencerdaskan anak bangsa, maka kualifikasi guru disini harus memiliki jiwa yang terbaik, berwibawa, dapat menjadi contoh bagi anak bangsa.

Menurut Undang-Undang RI Tahun 2005 pasal 1 menjelaskan bahwa Negara Indonesia sudah menetapkan guru PAUD sebagai profesi yang utama didalam mendidik dan mengajar anak dengan berbagai keahlian, kemahiran, maupun kecakapan dari segi psikis maupun intelektual. Maka guru PAUD yang menguasai keilmuan PAUD disegala bidang Pembelajaran PAUD tidak luput dari pemberian stimulus dan rangsangan berupa kegiatan-kegiatan yang menyenangkan untuk mengembangkan aspek pertumbuhan dan perkembangan anak (Mulyasa.H.E., 2012). Direktorat Jenderal Pembelajaran dan Kemahasiswaan Kementeritan Riset, (2017) menyatakan bahwa Adanya pedoman guru yaitu guru harus bersaing mencerdaskan anak bangsa sesuai dengan Undang-Undang Tahun 2014 tentang Kualifikasi Guru dan Dosen yang harus memiliki kompetensi, potensi, sehat jasmani dan rohani. Inilah sebabnya jikalah kebijakan pemerintah menerapkan profesi guru PAUD berkualifikasi S1 jurusan PAUD ataupun Psikologi agar dapat menerapkan dan mengaplikasikan pendidikan bagi anak usia dini. 
Menurut Didik Purwanto selaku Kepala Sekolah TK/RA Al-Furqon ada beberapa guru yang bukan lulusan PG PAUD. Jumlah guru yang ada di bagian TK/RA Al-Furqon sebayak 17 orang. Diantara guru-guru tersebut ada yang berstatus guru yang lulusan PAUD dan guru bukan lulusan PAUD. Guru yang lulusan PAUD adalah beberapa guru yang mempunyai gelar sarjana dari lulusan PAUD dalam studinya di perguruan tinggi. Sedangkan guru yang bukan lulusan PAUD adalah guru yang menempuh studinya bukan dari PAUD atau sebaliknya. Guru-guru ini hanya menempuh studinya sampai tingkat SMK, Pondok Pesantren dan lain sebagainya. Hal inilah yang menjadi kendala bagi pengajaran pendidikan Islam di Lembaga. Kendala mereka adalah mereka belum mahir dan kurangnya ilmu pengetahuan mengenai ilmu PAUD untuk sebuah pengajaran di kelas dan di luar kelas. Sama halnya dengan dengan guru yang bukan lulusan PAUD, mereka mengajar hanya sekedar mengajar, mereka kurang memahami ilmu mengenai psikologi anak dan ilmu mengenai PAUD. Maka jikalah seorang guru belum menempuh ke jenjang pendidikan selanjutnya akan tetapi mereka langsung bekerja sebagai guru maka, guru tersebut belum dikatakan guru yang berprofesional.

Hasil penelitian menyatakan bahwa guru yang memiliki kualifikasi profesional adalah guru yang dapat menjadikan anak bangsa cerdas, trampil agar dapat bersaing di dunia pendidikan dunia. Guru yang profesional harus memiliki ambisi dan komitmen yang tinggi dalam mengabdi di masyarakat, dapat membimbing, serta membina peserta didiknya agar memiliki kreativitas, potensi, serta intelegensi yang baik agar meningkatkan mutualisme pendidikan bangsa (Syaifullah, 2018). Penelitian yang lain menyatakan bahwa peran guru profesional dalam pendidikan Islam anak usia dini dilakukan oleh Asmi Rahma tahun 2017 penelitian skripsi yang berjudul " Peran Guru Anak Usia Dini di RA Bintang Kecil Wirobrajan Yogyakarta dalam Perspektif Pendidikan Islam " menjadi penelitian terhadap profesional guru dalam pendidikan Islam. Hasil penelitian menyatakan bahwa peran guru profesional dapat dilihat dari peranan guru dalam mengembangkan potensi anak didik dalam berbagai bidang, terutama pendidikan Islam anak yang meliputi guru harus bisa menjadi murobbi yaitu penasehat, motivator, pengajar, pengasuh, contoh yang baik bagi anak didik. Guru sebagai mudarris yaitu guru sebagai fasilitator, pengasuh, motivator, pelatih dan pengajar. Guru sebagai muadibb yaitu guru sebagai fasilitator, penasehat dan model. Guru sebagai mu'alim.yaitu peran guru sebagai pengajar. Semua itu diranah pendidikan Islam untuk anak usia dini (Asmi Rahmah, 2017).

Penelitian kedua, yaitu adanya peran guru profesional dari penelitian Leli dan Agus tahun 2019 dalam penelitian yang berjudul " Peran Guru dalam Mengembangkan Nilai Agam dan Moral Pada Anak Usia Dini di Raudhatul Atfhfal Maarif 1 Metro. Hasil penelitian menyatakan bahwa adanya penerapan pendidikan Islam secara profesional yang dilakukan oleh guru di Raudhatul Atfhfal Maarif 1 Metro diantaranya adalah guru menciptakan hubungan yang baik yaitu menjadi publick figur utama bagi anak, guru menjadi suri tauladan untuk menerapkan pendidikan Islam yang berfokus pada pengembangan akhlak dan agama anak, guru memberikan latihan prilaku kepada anak agar mereka dapat membedakan mana perilaku baik dan mana prilaku yang buruk dan tidak boleh dilakukan. Selain itu, guru memberikan motivasi dan cerita islami sebagai pengembangan Pendidikan Islam bagi anak, serta guru mengevaluasi pembelajaran anak secara berkesinambungan (Leli \& Agus, 2019).

Adanya penelitian-penelitian tersebut menjadikan profesional guru itu penting untuk diterapkan kepada anak. Maka perlu adanya Penyeleksian guru PAUD yang harus dilakukan agar kepala sekolah mendapatkan informasi yang akurat mengenai kualitas diri yang dimiliki calon guru PAUD. Kompetensi yang diisyaratkan harus memiliki latar belakang keilmuan PAUD, berkepribadian baik, dapat mencintai anak-anak, serta dapat menjadi suri tauladan bagi mereka. Hal tersebut dapat memicu timbulnya guru PAUD yang profesional dipicu oleh penguasaan keilmuan PAUD dalam pengajaran dan pembelajarannya serta berkepribadian yang menyenangkan kepada anakanak. Maka adanya kompetensi profesional yang dimiliki oleh guru yaitu kemampuan untuk memahami pertumbuhan dan perkembangan anak, pengasuhan anak, membimbing anak, melindungi anak, memberikan kasih sayang kepada anak, memahami standart perkembangan anak, memahami emosional anak, bahkan dapat menjadi teman sekaligus ibu di sekolah (Christianti, 2015). Inilah sebabnya guru PAUD mempunyai peranan penting dalam memeberikan pendidikan yang baik agar dapat menumbuhkan dan mengembangkan pertumbuhan dan perkembangan anak usia dini di Sekolah.

Pendidikan yang baik adalah pendidikan yang berlandaskan atas keTuhanan Yang Maha Esa. Pendidikan Islam anak usia dini adalah lembaga pendidikan untuk anak usia dini yang menerapkan sistem agama ke dalam program pembelajarannya. Lembaga Pendidikan Islam Anak Usia Dini meliputi RA (Raudhatul Atfal), BA (Bustanul Atfal). Yang membedakan antara lembaga RA/BA dengan TK/KB/PAUD adalah ada pada program pembelajaran IMTAQ (pembelajaran Iman dan Taqwa) yang diterapkan dan dibiasakan di lembaga TK. Kualifikasi guru yang ada 
pada PAUD Islam haruslah memenuhi kriteria keislaman. Kritreria tersebut ada pada pendidikan yang diajarkan oleh Abdullah Nashih Ulwan yang meneytakan bahwa guru anak usia dini harulah jujur, berwibawa, mempunyai sifat ikhlas, dapat membaca Al-Qur'an, penyayang (Ulwan, 2015). Berikut gambaran analisis kepribadian muslim dan muslimah guru PAUD menurut Abdullah Nashih Ulwan

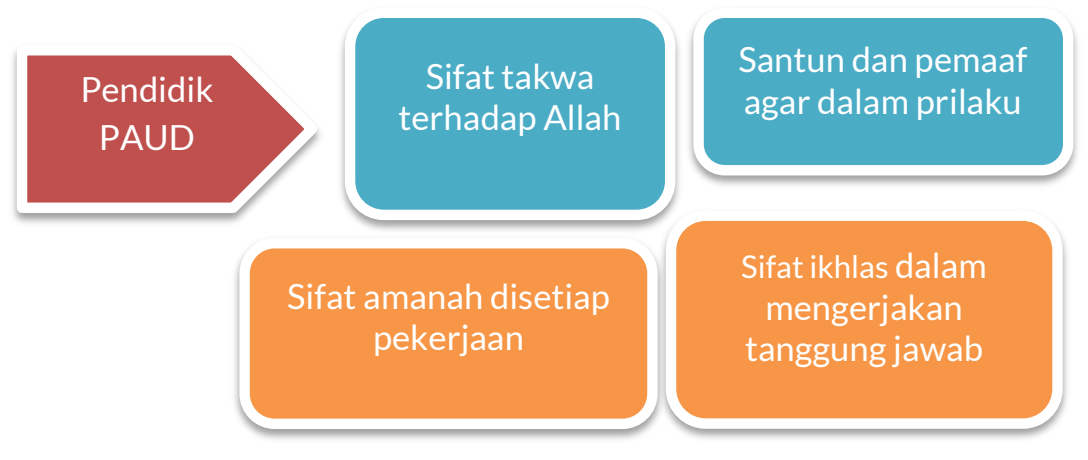

\section{Gambar 2 Analisis Profesionalitas Guru dalam PIAUD menurut Abdullah Nashih Ulwan}

Menurut gambar di atas, adanya karakter-karakter yang harus dimiliki guru dalam mendidik anak usia dini. Adanya sifat tersebut maka sudah seharusnya seorang guru harus menjadi suri tauladan bagi anak didiknya. Banyak diantara guru PAUD yang kurang menerapkan hal tersebut pada kegiatan pembelajarannya. Ada sebagian dari guru yang masih melakukan tindak kekerasan pada anak didiknya, kurang perhatian, bahkan kurang sabar dan telaten saat mengasuh dan membimbing anak. Maka tidak heran jikalah semboyan Ki Hajar Dewantara yang menyatakan bahwa "Ing Ngarso Sung Tulodho, Ing madyo Mangun Karso, Tut Wuri Handayani". Semboyan tersebut diaplikasikan pada pendidikan Islam untuk anak usia dini dalam buku taman siswanya.

Guru yang profesional harus mengaplikasikan pembelajaran dan pengajaran terhadap pendidikan Islam bagi anak-anak agar mereka dapat membiasakan hidup yang baik dan berkarakter Islami. Adanya penelitian terkait profesional guru menurut Ki Hajar Dewantara terhadap pendidikan Islam yang mengemukakan bahwa adanya landasan terpenting dalam pendidikan Islam bagi anak. Hal ini dengan adanya tuntunan yang harus dilakukan oleh guru terhadap anak usia dini untuk penunjang pertumbuhan dan perkembangan anak-anak dengan memberikan suri tauladan yang baik, budi pekerti yang baik. Hal tersebut dapat menciptakan kodrat anak agar selalu mencintai Allah sebagai TuhanNya, dan Muhammad sebagai Nabinya. Ilmu pengetahuan yang didapat di sekolah harus setara antara ilmu umum dan ilmu agama karena hal tersebut nantinya akan berguna bagi mereka di masa depannya kelak (Deden, 2014). Berikut analisis gambaran profesionalitas guru terhadap pendidikan Islam menurut Ki Hajar Dewantara
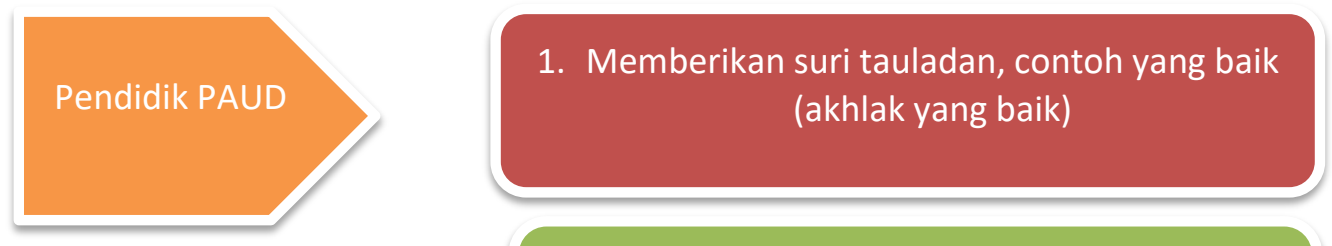

2. Memberikan kesemangatan belajar ilmu agama dan umum di usia dini

3. Memberikan dorongan agar tidak menyerah, selalu bertawakal dan berserah diri kepada Allah

Gambar 3 Analisis Peran Guru dalam Edukasi Spiritual Keagamaan Anak Usia Dini menurut Ki Hajar Dewantara 
Skema diatas menggambarkan makna dari semboyan pendidikan Ki Hajar Dewantara yang dapat diaplikasikan kedalam pendidikan Islam Anak Usia Dini. Mengingat bahwa Pendidikan Islam adalah sebuah pendidikan yang berpusat pada agama maka profesionalitas guru dalam mengajarkan pendidikan Islam anak melalui berbagai kegiatan yang islami. Guru PAUD harus bersifat menyenangkan yang dilakukan guru terhadap anak adalah dapat menjadikan dirinya sebagai idola, tokoh, panutan, teman bermain bagi anak. Selain itu guru juga dapat menjadi pengajar yang profesional ketika ia mahir untuk mengembangkan bahan ajar yang menyenangkan untuk kegiatan anak (Yusutria, 2017). Selain itu, guru juga berperan aktif dalam membimbing dan melatih anak usia dini dengan cara belajar sambil bermain guna mengembangkan potensi kepribadian, intektual, sosial, maupun spiritual anak (Masnipal, 2018).Berikut penulis analisis ruang lingkup pendidikan Islam yang wajib diajarkan oleh guru PAUD dalam pembelajarannya yang peneliti analisis dari Kitab Tarbiyatul Aulad Fil Islam karangan Abdullah Nashih Ulwan.

Tabel 4 Analisis Ruang Lingkup edukasi Spiritual Keagamaan Anak Usia Dini menurut Abdullah Nashih Ulwan

\begin{tabular}{cll}
\hline \hline $\begin{array}{c}\text { Ruang lingkup Pendidikan } \\
\text { Islam }\end{array}$ & \multicolumn{1}{c}{ Materi } & \multicolumn{1}{c}{ Metode } \\
\hline $\begin{array}{c}\text { Pendidikan Islam Perspektif } \\
\text { Akidah }\end{array}$ & $\begin{array}{l}\text { Mengajarkan lafadz Tauhid, mengajarkan ibadah, } \\
\text { mengajarkan membaca Al-Qur'an }\end{array}$ & $\begin{array}{l}\text { Pembiasaan } \\
\text { nasehat, pengawasan, } \\
\text { pelatihan }\end{array}$ \\
\hline Pendidikan Islam Perspektif \\
Akhlak & $\begin{array}{l}\text { Akhlak yang Mulia (jujur, berbakti ke orangtua, } \\
\text { berbuat baik terhadap sesama), mengajarkan } \\
\text { anak untuk Menjaga Lisan dari Perkataan, } \\
\text { Mengajarkan anak agar tidak berbohong }\end{array}$ & $\begin{array}{l}\text { Pembiasaan, } \\
\text { pelatihan, } \\
\text { pembimbingan,pengajaran, } \\
\text { pengasuhan }\end{array}$ \\
\hline \multirow{2}{*}{$\begin{array}{c}\text { Pendidikan Islam Perspektif } \\
\text { Sosial }\end{array}$} & $\begin{array}{l}\text { Mengajarkan anak untuk mengasihi terhadap } \\
\text { orang lain, Menghindarkan anak perilaku tidak } \\
\text { baik. }\end{array}$ & $\begin{array}{l}\text { Pelatihan,eksperimen, } \\
\text { pengawasan, pengajaran, } \\
\text { keteladanan, Pembiasaan }\end{array}$ \\
\hline \hline
\end{tabular}

Tabel diatas menjelaskan bahwa adanya suatu ruang lingkup pendidikan Islam yang diajarkan oleh anak usia dini di Sekolah. Ruang lingkup pendidikan Islam anak usia dini ini mencangkup pendidikan akidah, akhlak, dan sosial anak. Semua cakupan tersebut berguna sebagai landasan dasar untuk menerapkan pendidikan yang rohmatal lil alamin yaitu pendidikan yang mampu membawa anak untuk dekat dengan Allah SWT. Pendapat ini juga dipakai oleh Al-Ghazali yang menyatakan bahwa peran guru PAUD adalah sebagai pendidik sekaligus pengajar pendidikan Islam yang mampu menyempurnakan pendidikan yang lainnya, agar hati serta perilaku anak dapat terarahkan sesuai pedoman pendidikan Islam yaitu Al-Qur'an dan Hadis Nabi (Magfi, 2020). Pendapat tersebut dikuatkan oleh teori Montesori yang menyatakan bahwa pendidikan Islam yang diperuntukkan oleh anak usia dini bersumber pada Al-Qur'an yang dapat menjadikan anak terlatih untuk berprilkau baik sesuai tuntunan isi yang terkandung dalam Al-Qur'an (Fajarwati, 2014).

Harus diingat dan dimengerti bahwa Guru PAUD dapat menjadi profesional apabila mereka mampu untuk mendidik, membimbing, melatih, mengasuh peserta didik ketika di sekolah (Novan Ardi Wiyani, 2016). Secara langsung guru menjadi profesional dengan bantuan metode pengajaran yang cocok dan sesuai dengan kegiatan dan aspek ruang lingkup pendidikan yang diterapkan. Metode pembelajaran ini dapat dimaksud sebagai tata cara atau teknik guru dalam mengajarkan, mempermudah, menerangkan pembelajaran bagi anak usia dini (Fadillah, 2012). Ada banyak metode yang telah digunakan dan diterapkan seperti pada tabel diatas, misalnya adalah metode keteladanan, pembiasaan, nasehat atau bercerita, pengawasan, hukuman dan pelatihan. Tugas guru disini adalah menyediakan kegiatan pembelajaran yang menyenangkan dan tidak monoton sesuai dengan metode yang digunakan dalam pembelajaran. metode pengajaran ini bertujuan untuk membentuk karakter agama dan akhlak anak melalui pembiasaan-pembiasaan yang mereka lakukan dalam kesehariaanya (Cahyaningrum, Sudaryanti, \& Purwanto, 2017). Maka peneliti menyarankan kepada guru harus menjadi tauladan yang baik bagi anak didiknya, memberikan pengajaran yang menyenangkan serta menggunakan metode yang menyenangkan dan bermanfaat agar dapat menjadi timbal balik bagi kepribadian anak didik.

Penerapan metode pembelajaran juga berpengaruh pada profesionalitas guru dalam menerapkan pendidikan Islam anak usia dini. Adanya penelitian yang mencangkup hal tersebut, adalah penelitian milik Wardah Anggraini (2018) dalam penelitian jurnalnya yang berjudul "Penggunaan Metode Uswah Khasanah dalam mengembangkan Nilai-Nilai Moral Agama Anak Usia 5-6 Tahun di RA Al- Huda Wargomulyo Kecamatan 
Pardasuka Kabupaten Pringsewu" mempunyai hasil penelitian yang menyatakan bahwa metode Uswah Khasanah atau keteladanan merupakan metode yang cocok digunakan untuk mencontohkan pendidikan Islam dalam pengembangan moral agama anak yang mencangkup menghafal surat-surat pendek, doa sehari-hari, hidup sederhana, saling tolong menolong, berbuat baik antar sesama, ibadah sholat, mengaji Al-Qur'an serta berbagai kegiatan keagamaan lainnya. Guru menjadi suri tauladan utama dalam penelitian ini. guru yang baik dapat dijadikan contoh yang baik bagi anak didiknya ketika proses pembelajaran berlangsung di Sekolah. (Anggraini, 2018).

\section{SIMPULAN}

Adanya Tripusat Pendidikan yaitu keluarga, sekolah, masyarakat menurut Abdullah Nashih Ulwan dan Ki Hajar Dewantara yang menjadikan asas bagi edukasi spiritual keagamaan anak usia dini. Edukasi ini mencangkup aspek agama, moral, dan sosial anak. TK Al-Furqon menjadi salah satu implementasi edukasi spiritual keagamaan bagi anak, yang melibatkan guru sebagai sistem among dalam kegiatan pondok Ramadhan, santunan anak yatim, kaum duafa, panti jompo, menghafal Al-Qur'an. Inilah program dasar Tri Pusat pendidikan yang melibatkan lingkungan keluarga, sekolah maupun masyarakat. Maka guru harus memiliki kepribadian yang berkualifikasi yaitu tanggung jawab, berwibawa, sopan, beriman, dan berakhlak mulia.

\section{DAFTAR PUSTAKA}

Agus Wibowo. (2012). Pendidikan Karakter AUD. Yogyakarta: PT Pustaka Pelajar.

Ananda, R. (2017). Implementasi Nilai-nilai Moral dan Agama pada Anak Usia Dini. Jurnal Obsesi: Jurnal Pendidikan Anak Usia Dini, 1(1), 19-31. https://doi.org/10.31004/obsesi.v1i1.28

Anggraini, W. (2018). Penggunaan Metode Uswah Khasanah dalam mengembangkan Nilai-Nilai Moral Agama Anak Usia 5-6 Tahun di RA Al- Huda Wargomulyo Kecamatan Pardasuka Kabupaten Pringsewu. Skripsi, 3(1), 1-119.

Arif Rahman Hakim. (2012). Tarjamah Kitab Tarbiyahtul Aulaud Fil Islam (Pendidikan Anak Dalam Islam). Surakarta: PT Insan Kamil.

Ariyanti, T. (2016). Pentingnya Pendidikan Anqk Usia Dini bagi Tumbuh Kembang Anak. PGPAUD Universitas Muhammadiyah Purwokerto, 8(ISSN: 2655-870X), 50-58. https://doi.org/10.30595/dinamika.v8i1.943

Asmi Rahmah. (2017). Peran Guru Anak Usia Dini di Bintang Kecil Wirobrajan Yogyakarta dalam Perspektif Pendidikan Islam. UIN Sunan Kalijaga Yogyakarta.

Aziz, H. (2017). Guru Sebagai Role Model Pendidikan Karakter Anak Usia Dini Perspektif Pendidikan Islam dan Ki Hajar Dewantara. Golden Age: Jurnal IImiah Tumbuh Kembang Anak Usia Dini, 1(2), 1-14. Retrieved from http://ejournal.uin-suka.ac.id/tarbiyah/index.php/goldenage/article/view/1253

Cahyaningrum, E. S., Sudaryanti, S., \& Purwanto, N. A. (2017). Pengembangan Nilai-Nilai Karakter Anak Usia Dini melalui Pembiasaan dan Keteladanan. Jurnal Pendidikan Anak, 6(2), 203-213. https://doi.org/10.21831/jpa.v6i2.17707

Carol S Lidz. (2002). Early Childhood Asesment. Canada: Library of Congress cataloging.

Christianti, M. (2015). Profesionalisme Pendidik Anak Usia Dini. Jurnal Pendidikan Anak, 1(1), 112-122. https://doi.org/10.21831/jpa.v1i1.2923

Darmadi, H. (2015). MENJADI GURU PROFESIONAL diperbincangkan , karena guru merupakan sumber kunci keberhasilan pendidikan . didik yang menyangkut berbagai aspek yang bersifat manusiawi yang unik dalam. Jurnal Edukasi, 13(2), 161-174.

Daud, A. (2019). BOOK REVIEW Metode Mendidik Anak dalam Perspekif Islam. Turast: Jurnal Penelitian Dan Pengabdian, 4(2), 207-216. https://doi.org/10.15548/turast.v4i2.349

Deden, M. (2014). Guru Profesional Menurut Ki Hajar Dewantara dan Relevansinya dengan Perkembangan Pendidikan Islam di Indonesia. Pendidikan Indonesia.

Dewantara, K. H. (1977). Pendidikan. Yogyakarta: Majelis Luhur Persatuan Taman Siswa.

Direktorat Jenderal Pembelajaran dan Kemahasiswaan Kementeritan Riset, T. dan P. T. 2017. (2017). Pedoman Penyelenggaraan Pendidikan Profesi Guru. Journal of Chemical Information and Modeling. https://doi.org/10.1017/CBO9781107415324.004

Fadillah, M. (2012). Desain Pembelajaran PAUD Tinjauan Teoritik \& Praktik (p. 12). p. 12. Yogyakarta: Ar-Ruz Media.

Fajarini, U. (2014). Peranan Kearifan Lokal Dalam Pendidikan Karakter : Vol. 1, No. 2. Sosio Didaktika, 1(2).

Fajarwati, I. (2014). Konsep Montesori Tentang Pendidikan Anak Usia Dini Dalam Perspektif Pendidikan Islam. Pendidikan Agama Islam, 11(1).

Harpansyah. (2017). Pendidikan Anak dalam Perspektif Abdullah Nashih Ulwan (Telaah atas Kitab Tarbiyatul Aulad Fil Islam) (Raden Fatah Palembang; Vol. 01). Retrieved from http://www.albayan.ae 
Ibrahim, T., \& Hendriani, A. (2017). Kajian Reflektif tentang Etika Guru dalam Perspektif Ki Hajar Dewantara Berbalut Filsafat Moral Utilitarianisme. NATURALISTIC: Jurnal Kajian Penelitian Pendidikan Dan Pembelajaran, 1(2), 135-145. https://doi.org/10.35568/naturalistic.v1i2.12

Ikhwan, subandi, \& R. (2018). Konsep Pendidikan dalam Pemikiran Ki Hajar Dewantara dan Relevansinya dengan Pendidikan di Indonesia. Sumbula, 3(1), 850.

Inawati, A. (2017). Strategi Pengembangan Moral dan Nilai Agama Untuk Anak Usia Dini Asti Inawati. Al-Athfal Jurnal Pendidikan Anak, 3(1), 51-64.

Istiadie, J., \& Subhan, F. (2016). Pendidikan Moral Perspektif Nashih Ulwan. Jurnal Pendidikan Agama Islam (Journal of Islamic Education Studies), 1(1), 45. https://doi.org/10.15642/pai.2013.1.1.45-60

Juhji. (2016). Guru, Mendidik, Mengajar, Nilai, Pembentukan Kepribadian, Panutan. Jurnal IImiah Pendidikan Studia Didaktika, 10, n. 01,(ISSN 1978-8169), 61.

Karoso, S., \& Trihantoyo, S. (2017). Kepemimpinan Kepala Sekolah dalam Pelaksanaan Program Pengembangan dan Peningkatan Seni Tradisional Jenjang SD, SMP, dan SMA di Provinsi Jawa Timur. Jurnal ABDI, 2(2), 34. https://doi.org/10.26740/ja.v2n2.p34-39

Khairil Mustofa. (2014). Konsep Pendidikan Islam Menurut Dr. Abdullah Nasih Ulwan. Jurnal Study Islam Panca Wahana, 12, 84-94.

Ki Suratman. (1987). Pokok-Pokok Ketaman Siswaan. Yogyakarta: Majelis Luhur Persatuan Taman Siswa.

Leli \& Agus. (2019). Peran Guru dalam Mengembangkan Nilai Agam dan Moral Pada Anak Usia Dini di Raudhatul Atfhfal Maarif 1 Metro. Selling Jurnal Program Studi PGRA, 5(1).

Magfi, F. (2020). Peran Seorang Pendidik dalam Pendidikan Islam. Kompasiana.Com. Retrieved from https://www.kompasiana.com/firdamaghfirrotusamalia/5e79fcb6097f3679b11f09c2/peran-seorangpendidik-dalam-pendidikan-islam

Majid, A. (2013). Strategi Pembelajaran. Bandung: PT Remaja Rosdakarya.

Masnipal. (2018). Menjadi Guru PAUD Profesional. In Menjadi Guru PAUD Profesional (p. 400). Jakarta: Elex Media Komputindo.

Mulyasa.H.E. (2012). Manajemen PAUD. Bandung: PT Remaja Rosdakarya.

Nata, A. (2012). Pemikiran Pendidikan Islam dan Barat. Jakarta: PT. Raja Grafindo Persada.

Novan Ardi Wiyani. (2016). Konsep Dasar PAUD. Yogyakarta: Gava Media.

Nugroho, W. (2018). Implementasi Trilogi Ki Hadjar Dewantara di SD Taman Muda Jetis Yogyakarta. Edukasi Journal, 101), 41-54. https://doi.org/10.31603/edukasi.v10i1.2031

Nurhayati. (2013). Membangun Karakter melalui Trilogi dan Tripusat Pendidikan. Jurnal Perspektif Pendidikan, Vol 6 No 1(Vol 6 No 1 (2013): Jurnal Perspektif Pendidikan), 103-110. Retrieved from https://ojs.stkippgri-lubuklinggau.ac.id/index.php/JPP/article/view/364

Nurmalasari, R., Dian, R., Wati, P., Puspitasari, P., Diana, W., \& Dewi, N. K. (2013). Peran Guru dalam Kurikulum 2013. Aspirasi, 722-733. https://doi.org/https://doi.org/10.22212/aspirasi.v4i1.480

Pradipto, D. (2007). Belajar Sejati VS Kurikulum Nasional(PT Kanisius, Ed.). Yogyakarta.

Rohmah, N. (2016). Bermain dan Pemanfaatannya Dalam Perkembangan Anak Usia Dini. Jurnal Tarbawi, Volume 13(2), 27-35. https://doi.org/10.34001/TARBAWI.V13I2.590

Rohmatun Nurul Hidayah. (2015). Pendidikan Anak Usia Dini Perspektif Ki Hajar Dewantara. Jurnal Studi Islam Dan Sosial, 92).

Rosadi, S. (2019). Kasus Masih diproses Polri, Guru Aniaya Murid PAUD di Samarinda. Retrieved from Merdeka.com website: https://m.merdeka.com/peristiwa/kasus-masih-diproses-polri-guru-aniaya-muridpaud-di-samarinda-kabur.html

S.Mohammad. (2016). Akhlak Guru dalam Pengajaran dan Pembelajaran Pendidikan Islam. Akademika, 86(02). https://doi.org/10.17576/akad-2016-8602-02

Samho, B., \& Yasunari, O. (2013). Konsep Pendidikan Ki Hadjar Dewantara dan Tantangan-Tantangan Implementasinya Di Indonesia Dewasa ini. Journal of Chemical Information and Modeling, 53(9), 16891699. https://doi.org/10.1017/CBO9781107415324.004

Saripudin, A., \& Faujiah, I. Y. (2018). Strategi Edutainment dalam Pembelajaran di PAUD (Studi Kasus pada TK di Kota Cirebon). AWLADY : Jurnal Pendidikan Anak, 4(1), 129. https://doi.org/10.24235/awlady.v4i1.2637

Sudaryanti, S. (2017). Mendidik Anak Menjadi Manusia yang Berkarakter. Jurnal Pendidikan Anak, 3(2). https://doi.org/10.21831/jpa.v3i2.11706

Sugiyono. (2015). Metode Penelitian Pendidikan.Pendekatan Kuantitatif, Kualitatif, dan R\&D. Bandung; Penerbit Alfabeta.

Susilo, S. V. (2018). Refleksi Nilai-Nilai Pendidikan Ki Hadjar Dewantara dalam Upaya Upaya Mengembalikan Jati Diri Pendidikan Indonesia. Jurnal Cakrawala Pendas, 4(1). https://doi.org/10.31949/jcp.v4i1.710

Suyadi. (2011). Manegemen PAUD, TPAKB-TK/RA. Yogyakarta: Pustaka Pelajar.

Syaifullah, S. (2018). Analisis Pengembangan Profesional Pendidik dan Tenaga Kependidikan di SMAN 2 Wera Kabupaten Bima. EDU SOCIATA ( JURNAL PENDIDIKAN SOSIOLOGI ), 1(2), 1-9. https://doi.org/10.33627/es.v1i2.19 
Syaikhudin, A. (2012). Konsep Pemikiran Pendidikan menurut Paulo Freire dan Ki Hajar Dewantoro. Cendekia: Jurnal Kependidikan Dan Kemasyarakatan, 10(1), 79. https://doi.org/10.21154/cendekia.v10i1.403

Trimutia, R. (2019). Bocah 3 Tahun Terjatuh dari Lantai 2 Gedung PAUD di Menteng. M.Liputan5.Com. Retrieved from https://m.liputan5.com/news/read/3914572/bocah-3-tahun-terjatuh-dari-lantai-2-gedung-paud-dimenteng,

Ulwan, A. N. (2015). Kitab Tarbiyyatul Aulad Fil Islam. Mesir: PT Darussalam.

Utami, P. N. (2017). Konsep pendidikan karakter menurut ki hajar dewantara. Skripsi, Fakultas Tarbiyah Dan IImu Keguruan, IAIN SALATIGA, 1-95.

Wiyani, N. A. (2017). Optimalisasi Kecerdasan Spiritual bagi Anak Usia Dini menurut Abdullah Nashih Ulwan. ThufuLA: Jurnal Inovasi Pendidikan Guru Raudhatul Athfal, 4(2), 77. https://doi.org/10.21043/thufula.v4i2.2009

Yusuf, U. A. (2017). Manajemen Pendidikan Akhlak Menurut Abdullah Nashih Ulwan (Studi Kitab Tarbiyah AlAulād Fī Al-Islām). Edukasi Islami, 06(12), 63-80. https://doi.org/: http://dx.doi.org/10.30868/ei.v6i12.179

Yusutria. (2017). Profesionalisme Guru Dalam Meningkatkan Kualitas Sumber Daya Manusia. Jurnal Curricula, 2(1), 38-46.

Zainal aqib. (2013). Belajar dan Mengajar pada Taman Kanak-Kanak. Bandung: Balai Pustaka. 